\title{
ANALISIS TINGKAT KERAWANAN LONGSOR LERENG DI DESA SAMUDERA KULON KECAMATAN GUMELAR KABUPATEN BANYUMAS
}

\section{ANALYSIS OF THE LEVEL OF SLOPE LANDSLIDE VULNERABILITY IN SAMUDERA KULON VILLAGE GUMELAR SUB-DISTRICT BANYUMAS REGENCY}

\author{
Iskahar $^{1}$, Sulfah Anjarwati ${ }^{1}$, Windi Febriana Sohebah ${ }^{2}$ \\ ${ }^{12}$ Program Studi S1 Teknik Sipil, Fakultas Teknik dan Sains \\ Universitas Muhammadiyah Purwokerto
}

\section{Informasi Artikel \\ Dikirim, \\ Direvisi, \\ Diterima,}

\section{Korespondensi Penulis:}

\section{Iskahar}

Program Studi Teknik Sipil Universitas Muhammadiyah Purwokerto

JL. K.H. Ahmad Dahlan

Purwokerto, 53182

Email:

iskaharoke@gmail.com

\section{ABSTRAK}

Samudera Kulon Village is one of the villages in Gumelar Subdistrict, which is an area of high vulnerability to landslides. This study aims to determine how much the level of landslide hazard in Samudera Kulon, Gumelar District. Data is obtained through direct observation in the field and secondary data from various related agencies. Data analysis was carried out to determine the typology of landslide potential zones and determine the classification of the level of vulnerability to landslides. The results of data analysis showed that the landslide hazard level was between 1.74-2.225, so the level of landslide hazard potential in Samudera Kulon Village was moderate.

Kata Kunci : Landslide, Slope, Gumelar

Desa Samudera Kulon merupakan salah satu desa di Kecamatan Gumelar yang termasuk kawasan kerentanan tinggi terhadap bencana tanah longsor. Penelitian ini bertujuan untuk mengetahui seberapa besar tingkat kerawanan longsor di Samudera Kulon Kecamatan Gumelar..Perolehan data melalui pengamatan langsung di lapangan, dan data sekunder dari berbagai instansi yang terkait. Analisis data dilakukan untuk menetapkan tipologi zona berpotensi longsor dan menentukan klasifikasi tingkat kerawanan terhadap longsor.Hasil analisis data diperoleh tingkat kerawanan longsor antara 1,74 - 2,225 maka tingkat kerawanan zona berpotensi longsor Desa Samudera Kulon adalah sedang

Keyword : Kawasan, Lereng, Gumelar 


\section{PENDAhUluan}

Tanah longsor merupakan salah satu jenis bencana alam yang sering terjadi di Indonesia. Penyebab utama dari bencana tersebut adalah intensitas curah hujan yang mampu melunakkan tanah atau aktivitas kegempaan yang menimbulkan gaya dinamis akibat getaran atau rambatan dari pusat gempa sehingga terjadi slope atau ketidakstabilan lereng (Ilyas, 2011)

Faktor-faktor lain yang dapat memicu terjadinya tanah longsor adalah lereng yang terjal, terdapat lapisan tanah yang kurang padat dan tebal, jenis batuan yang kurang kuat ikatannya, jenis vegetasi yang tidak mendukung penguatan lereng, adanya beban tambahan dipermukaan tanah seperti pemukiman, penggundulan hutan dan pemanfaatan lahan yang tidak mendukung kestabilan lereng (Direktorat Jendral Penataan Ruang, 2007).

Kecamatan Gumelar terbagi dalam 10 desa yang masing masing-masing desa tidak jauh berbeda karakteristiknya terutama dalam hal kerawanan bencana, hal ini terlihat dari hasil pendataan bahwa wilayah Kecamatan Gumelar tergolong Rawan Tanah Longsor,kekeringan dan banjir. Selanjutnya wilayah atau desa yang masuk dalam kategori rawan tanah longsor salah satunya adalah desa Samudera Kulon. Oleh karena itu,desa ini menjadi wilayah studi penelitian ini.

Menurut pemerintah Desa Samudera Kulon, peristiwa bencana tanah longsor pada tahun 2020 belum mencatat adanya kejadian tanah longsor yang parah, hanya kejadian kecil seperti gugurannya tanah dibelakang pekarangan rumah yang tidak menimbulkan kerusakan secara materi, pada tahun 2019 terjadi longsor pada bulan januari yang menimpa jalan raya wilayah samudera kulon, dan yang parah kejadian tanah longsor terjadi pada 2 tahun lalu tepatnya pada tanggal 19 Februari 2018 banyak terjadi tanah longsor.

Tujuan dari penelitian ini adalah untuk mengetahui dan menganalisa tingkat kerawanan longsor di Desa Samudera Kulon, Kecamatan Gumelar.

\section{METODE PENELITIAN}

Penelitian ini menggunakan metode survei. Data yang dikumpulkan di maksudkan untuk mendapatkan faktor kondisi alam dan aktifitas manusia yang dapat menjadi faktor penyebab terjadinya tanah longsor dan analisis dengan pendekatan yang disusun oleh Direktorat Jenderal Penataan Ruang (2008).

\subsection{Waktu dan Lokasi Penelitian}

Dalam penelitian ini dilaksanakan pada bulan Juli 2020 di Desa Samudera Kulon ,Kecamatan Gumelar, Kabupaten Banyumas. Lokasi yang dipilih merupakan salah satu desa di Kecamatan Gumelar sebagai kawasan yang mempunyai potensi bahaya kelongsoran lereng (BPBD Banyumas ,2012)

\subsection{Alat dan Bahan Penelitian}

Alat yang digunakan dalam penelitian ini meliputi Laptop,Handphone,alat tulis dan form survey. Pengukuran dan pengambilan data kemiringan lereng dilakukan menggunakan software ArcGIS.

\subsection{Analisis Data}

Analisis data dalam penelitian ini adalah deskriptif kualitatif. Analisis deskriptif kualitatif merupakan data yang diambil berdasarkan fenomena yang ada dan teramati yang akan menghasilkan data yang menjelaskan secara rinci fakta yang ada di lapangan.

Data yang diperoleh dari survei berupa , tata air lereng, , pemotongan lereng, pencetakan kolam, drainase, pembangunan konstruksi. Data sekunder meliputi vegetasi,pola tanam,kemiringan lereng, batuan penyusun, curah hujan, kepadatan penduduk, usaha mitigasi, klasifikasi zona berpotensi longsor, peta daerah rawan bencana gerakan tanah.

Berdasarkan model pendugaan BBSDLP (2009), parameter-parameter yang digunakan untuk menentukan tingkat kerawanan tanah longsor adalah penutupan lahan (landcover), jenis tanah, kemiringan lahan, curah hujan, formasi geologi (batuan induk) dan kerentanan gerakan tanah.

Untuk mengukur tingkat kerawanan berdasarkan aspek fisik alami ditetapkan 7 (tujuh) indikator : kemiringan lereng, kondisi tanah, batuan penyusun lereng, curah hujan,tata air lereng,kegempaan, vegetasi. Sedangakan untuk mengukur tingkat kerawanan berdasarkan aspek aktifitas manusia yakni tingkat risiko kerugian manusia dari kemungkinan kejadian longsor ditetapkan 7 (tujuh) indikator : pola tanam, penggalian dan pemotongan lereng,pencetakan kolam, drainase, pembangunan konstruksi, kepadatan penduduk, usaha mitigasi.

\subsection{Tahap Studi}

Langkah-langkah yang diambil dalam penelitian ini adalah :

Studi Pustaka dan Literatur

CIVeng Vol.1, No.1, Januari 2020 : 1 10 
Studi Pustaka dan Literatur adalah studi kepustakaan yang guna mendapatkan dasar-dasar teori serta langkah-langkah penelitian yang berkaitan dengan analisis tanah longsor dan untuk mencari referensi penelitian yang sejenis.

\section{Pengumpulan Data}

- Data Primer merupakan Data yang diperoleh menganalisa lokasi penelitian secara langsung.Data yang diperlukan adalah Tata air lereng. Pemotongan lereng, Pencetakan kolam, Drainase, Pembangunan konstruksi.

- Data Sekunder merupakan data yang diperoleh dari sebuah instansi tertentu. Data yang diperlukan adalah Vegetasi,PolaTanam,Kemiringan lereng, Batuan penyusun,Curah hujan,Kepadatan penduduk,Usaha mitigasi,Klasifikasi zona berpotensi longsor,Peta daerah rawan bencana gerakan tanah

$\underline{\text { Analisis dan Pembahasan }}$

Setelah data diperoleh,selanjutnya adalah melakukan analisis dan perhitungan yang diperlukan untuk analisis kelongsoran. Langkah awal yaitu menganalisis kemiringan lereng dengan menginput kordinat lereng menggunakan ArcGIS 10.5 , selanjutnya pemberian nilai bobot sesuai dengan parameter dan kriterianya. Hasil analisis itu nantinya akan menghasilkan indeks sorie. Selanjutnya nilai kisaran ini dikonversi pada beberapa tingkat kerawanan

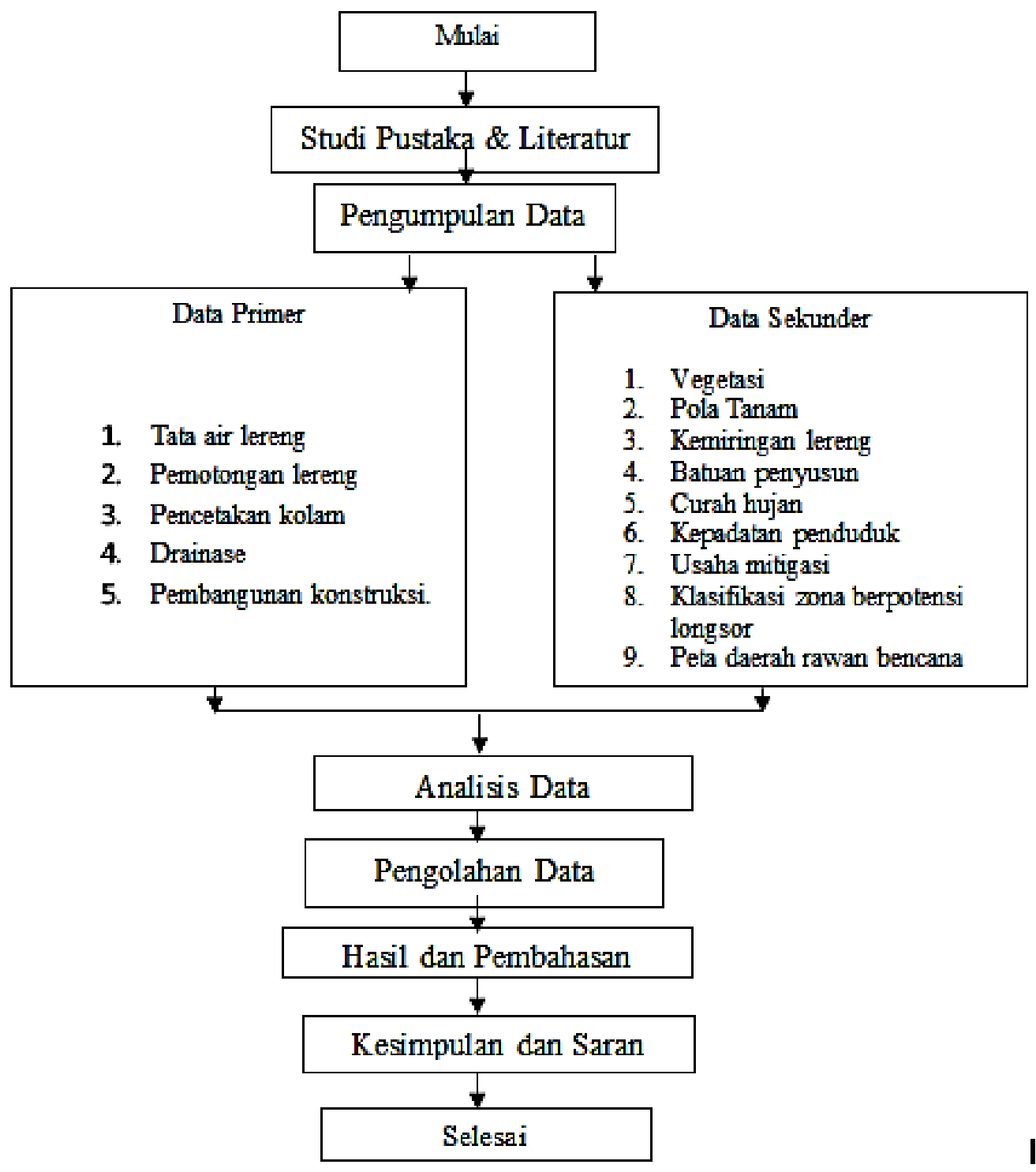


3. HASIL DAN PEMBAHASAN

3.1. Kondisi Fisik Desa Samudera Kulon

Kemiringan Lereng

Desa Samudera Kulon merupakan daerah yang memiliki perbukitan dan lereng-lereng yang relatif landai, dengan kemiringan 0\%-8\% serta >40\% dengan ketinggian di Desa Samudera Kulon yaitu $200 \mathrm{mdpl}-400 \mathrm{mdpl}$.

\section{$\underline{\text { Kondisi Tanah }}$}

Kondisi tanah pada Desa Samudera Kulon yaitu jenis tanah Latosol dan Podsolik. (Sumber : BAPEDA Kabupaten Banyumas Tahun 2012)

\section{Batuan Penyusun Lereng}

Batuan penyusun lereng pada desa Samudera Kulon secara umum adalah Batuan penyusun lereng Formasi Halang,. (Sumber : BAPEDA Kabupaten Banyumas Tahun 2012)

\section{Curah Hujan}

Data curah hujan Desa Samudera Kulon dari Stasiun Banjaranyar Kabupaten Banyumas . Data curah hujan yang digunakan ialah data curah hujan selama 10 tahun dari tahun 2010 - 2020. Dari data yang sudah diperoleh ,jadi rata rata curah hujan $3815 \mathrm{~mm} / \mathrm{tahun}$.

$\underline{\text { Kondisi Topografi }}$

Desa Samudera Kulon Kecamatan Gumelar mempunyai bentuk topografi perbukitan , kemiringan lereng alami perbukitan bervariasi antara $0-40 \%$.

\section{Kondisi Tata Lereng}

Lereng-lereng di Desa Samudera Kulon termasuk daerah yang jarang muncul rembesan air pada lereng, terutama pada bidang kontak antara batuan kedap dengan lapisan tanah.

\section{$\underline{\text { Kondisi Kegempaan }}$}

Badan Penanggulanagan Bencana Daerah (BPBD) Kabupaten Banyumas menegaskan bahwa Wilayah Kabupaten Banyumas bukan merupakan kawasan yang rawan terhadap bencana alam gempa bumi.

\section{Kondisi Vegetasi}

Pada umumnya tumbuhan adalah berakar tunjang seperti jati, pinus albasiar dan lain-lain. Namun terdapat pula tumbuhan berakar serabut seperti bambu. Bagian lereng yang agak datar dengan luasan yang terbatas, lahan dimanfaatkan untuk menanam tanaman musiman seperti ubi kayu meliputi : jagung,padi,palawija, ubi jalar, dan tanaman musiman lainnya.

\subsection{Kondisi aktivitas masyarakat Desa Samudera Kulon} Pemanfaatan lahan

Pemanfaatan lahan di Desa Samudera Kulon adalah untuk pertanian, perkebunan, perhutanan, pemukiman, bangunan sekolah dan perkantoran desa.Letak bangunan sangat dekat dengan lereng - lereng dengan kemiringan yang relatif curam dengan kemiringan antara $0-40 \%$.

\section{$\underline{\text { Pola tanam }}$}

Penduduk Desa Samudera Kulon sebagian besar adalah petani. Pertanian pada umumnya adalah dengan memanfaatkan lereng - lereng. Lereng ditanami dengan pola tanam musiman dengan jenis tanaman yaitu padi,jagung dan palawija.

\section{Penggalian dan pemotongan lereng}

Penggalian dan pemotongan lereng di Desa Samudera Kulon dilakukan untuk jalan atau bangunan dan pembangunan dengan intensitas sedang, tetapi kegiatan ini belum mempertimbangkan struktur pelapisan tanah/batuan dan perhitungan analisis kestabilan lereng.

\section{Pencetakan kolam}

Pengamatan di lapangan tidak ditemukan adanya pencetakan kolam di lereng. Lahan basah berupa sawah tadah hujan terdapat di beberapa tempat dengan luasan yang kecil dan tidak terkonsentrasi pada suatu tempat. 
Drainase

Sistem drainase di Desa Samudera Kulon secara umum sudah cukup memadai,karena hal ini terlihat di hampir sepanjang jalan Desa Samudera Kulon sudah ada bangunan drainase namun dengan kondisi yang kurang terawat.

\section{$\underline{\text { Pembangunan konstruksi }}$}

Pembangunan konstruksi di Desa Samudera Kulon adalah untuk peruntukan perumahan, bangunan sekolah, perkantoran desa, perhutanan serta pertanian dan perkebunan.Bangunan konstruksi pada umumnya terletak dibagian lahan agak datar atau hasil pemotongan lereng.

\section{$\underline{\text { Kepadatan Penduduk }}$}

Menurut data administrasi Desa Samudera Kulon luas wilayahnya adalah 920,982 $\mathrm{km}^{2}$ yang terdiri dari 9 Perdukuhan / Gerumbul yaitu Samudra, Tipar, Mengger, Bojong Sari, Cikadu, Sokanandi, Combong dan Sawangan , 3 Dusun, 5 RW dan 29 RT dengan jumlah penduduk 3103 orang . ( Data Administrasi Desa Samudera Kulon:2020)

\section{$\underline{\text { Usaha Mitigasi }}$}

Usaha - usaha mitigasi untuk mengurangi risiko terjadinya bencana tanah longsor di Desa Samudera Kulon sudah ada, baik oleh pemerintah daerah maupun masyarakat. Sebagai berikut usaha mitigasi pada Desa Samudera Kulon :pada tahun 2010 usaha mitigasi dilakukan oleh badan lppsh di grumbul cikadu, pada tahun 2018 usaha mitigasi dilakukan oleh badan kelompok tani hutan argo lestari dengan hasil yaitu pembuatan beronjong untuk penahan tanah, pembuatan tim desa tangguh bencana oleh pihak desa samudera kulon dengan tujuan untuk relawan jika terjadi bencana

Berdasarkan data diatas dan kondisi lapangan Desa Samudera Kulon yang berada pada ketinggian 200$400 \mathrm{mdpl}$, curah hujan rata rata pertahun yaitu $3815 \mathrm{~mm} /$ tahun, kemiringan lereng alami antara 0-40\%, maka titik lokasi pengamatan titik 1 termasuk zona type $\mathrm{C}$, titik 2 dan titik 3 termasuk zona tipe A.

\subsection{Pembahasan}

Tabel 1. Kriteria dan indikator tingkat kerawanan aspek fisik alami zona berpotensi longsor Tipe C Desa Samudera Kulon (Titik 1)

\begin{tabular}{|c|c|c|c|c|c|c|}
\hline \multicolumn{7}{|c|}{ C1 Kriteria Aspek Fisik Alami } \\
\hline No & Indikator & $\begin{array}{c}\text { Bobot } \\
\text { Indikator } \\
(\%)\end{array}$ & $\begin{array}{l}\text { Sensitivitas } \\
\text { Tingkat } \\
\text { Kerawanan }\end{array}$ & Veriver & $\begin{array}{c}\text { Bobot } \\
\text { Penilaian }\end{array}$ & $\begin{array}{c}\text { Nilai Bobot } \\
\text { Tertimbang } \\
\text { Kerawanan } \\
\text { Longsr } \\
\end{array}$ \\
\hline (1) & (2) & (3) & (4) & (5) & (6) & (7) \\
\hline 1 & $\begin{array}{l}\text { Kemiringan } \\
\text { Lereng }\end{array}$ & $30 \%$ & Rendah & Kemiringan lereng 0-8\%. & 1 & 0,30 \\
\hline 2 & Kondisi Tanah & $15 \%$ & Rendah & $\begin{array}{l}\text { Lereng tersusun oleh batuan dan tanah jenis } \\
\text { latosol yang, namun tidak ada struktur } \\
\text { retakan/kekar pada batuan. }\end{array}$ & 1 & 0,15 \\
\hline 3 & $\begin{array}{l}\text { Batuan Penyusun } \\
\text { Lereng }\end{array}$ & $20 \%$ & Sedang & $\begin{array}{l}\text { Lereng tersusun oleh batuan batu dan tanah } \\
\text { namun ada struktur retakan }\end{array}$ & 2 & 0,40 \\
\hline 4 & Curah Hujan & $15 \%$ & Tinggi & $\begin{array}{l}\text { Curah hujan mencapai } 70 \mathrm{~mm} / \mathrm{jam} \text { atau } 100 \\
\mathrm{~mm} / \text { hari curah hujan tahunan mencapai lebih } \\
\text { dari } 2500 \mathrm{~mm} / \mathrm{th} \text { yaitu } 3815 \mathrm{~mm} / \text { tahun } \\
\text { dilihat dari data rata rata curah hujan } \\
\text { tahunan }\end{array}$ & 3 & 0,60 \\
\hline 5 & Tata Air Lereng & $7 \%$ & Rendah & $\begin{array}{l}\text { Tidak terdapat rembesan- rembesan air atau } \\
\text { mata air pada lereng atau bidang kontak } \\
\text { antara batuan kedap dengan lapisan tanah } \\
\text { yang permeable. }\end{array}$ & 1 & 0,07 \\
\hline 6 & Kegempaan & $3 \%$ & Rendah & Lereng tidak termasuk daerah rawan gempa. & 1 & 0,03 \\
\hline 7 & Vegetasi & $10 \%$ & Tinggi & Q-tela pohon, pohon pisang.Pohon Bambu & 3 & 0,03 \\
\hline & Jumlah Bobot & $100 \%$ & & & & 1,58 \\
\hline
\end{tabular}

Sumber: Analisis 2020 
Tabel 2. Kriteria dan indikator tingkat kerawanan aspek aktivitas manusia zona berpotensi longsor Tipe C Desa Samudera Kulon (Titik 1)

\begin{tabular}{|c|c|c|c|c|c|c|}
\hline \multicolumn{7}{|c|}{ C2 Kriteria Aspek Aktivitas Manusia } \\
\hline No & Indikator & $\begin{array}{c}\text { Bobot } \\
\text { Indikator }(\%)\end{array}$ & $\begin{array}{l}\text { Sensitivitas } \\
\text { Tingkat } \\
\text { Kerawanan }\end{array}$ & Veriver & $\begin{array}{c}\text { Bobot } \\
\text { Penilaian }\end{array}$ & $\begin{array}{c}\text { Nilai Bobot } \\
\text { Tertimbang } \\
\text { Kerawanan } \\
\text { Longsr } \\
\end{array}$ \\
\hline (1) & (2) & (3) & (4) & (5) & (6) & (7) \\
\hline 1 & Pola Tanam & $10 \%$ & Tinggi & $\begin{array}{l}\text { Lereng ditanami dengan pola tanaman yang } \\
\text { tidak tepat dan sangat sensitif, berupa } \\
\text { tanaman perkebunan dengan jenis tanaman } \\
\text { ubi kayu seperti pohon Qt-tela,pohon bambu. } \\
\text { Jenis pohon tersebut memiliki akar yang tidak } \\
\text { cukup kokoh menjaga struktur tanah tetap } \\
\text { kuat.. }\end{array}$ & 3 & 0,30 \\
\hline 2 & $\begin{array}{l}\text { Penggalian dan } \\
\text { Pemotongan } \\
\text { Lereng }\end{array}$ & $20 \%$ & Rendah & $\begin{array}{l}\text { Tidak melakukan penggalian/ pemotongan } \\
\text { lereng }\end{array}$ & 1 & 0,20 \\
\hline 3 & $\begin{array}{l}\text { Pencetakan } \\
\text { Kolam }\end{array}$ & $10 \%$ & Rendah & Tidak melakukan pencetakan kolam. & 1 & 0,10 \\
\hline 4 & Drainase & $10 \%$ & Tinggi & Sistem drainase yang tidak memadai & 3 & 0,60 \\
\hline 5 & $\begin{array}{l}\text { Pembangunan } \\
\text { Konstruksi }\end{array}$ & $20 \%$ & Rendah & Tidak ada pembangunan Konstruksi & 1 & 0,20 \\
\hline 6 & $\begin{array}{l}\text { Kepadatan } \\
\text { Penduduk }\end{array}$ & $20 \%$ & Rendah & $\begin{array}{l}\text { Kepadatan penduduk rendah } \\
(<20 \mathrm{jiwa} / \mathrm{ha}) \text {. Yaitu } 3.130 \mathrm{jiwa} / \mathrm{ha}\end{array}$ & 1 & 0,30 \\
\hline 7 & Usaha Mitigasi & $10 \%$ & Sedang & $\begin{array}{l}\text { Terdapat usaha mitigasi bencana tapi belum } \\
\text { terkoordinasi dan } \\
\text { melembaga. }\end{array}$ & 2 & 0,20 \\
\hline & Jumlah Bobot & $100 \%$ & & & & 1,9 \\
\hline
\end{tabular}

Sumber : Analisis 2020

Tabel 3. Kriteria dan indikator tingkat kerawanan aspek fisik alami zona berpotensi longsor Tipe A Desa Samudera Kulon (Titik 2)

\begin{tabular}{|c|c|c|c|c|c|c|}
\hline \multicolumn{7}{|c|}{ C1 Kriteria Aspek Fisik Alami } \\
\hline No & Indikator & $\begin{array}{c}\text { Bobot } \\
\text { Indikator }(\%)\end{array}$ & $\begin{array}{l}\text { Sensitivitas } \\
\text { Tingkat } \\
\text { Kerawanan }\end{array}$ & Veriver & $\begin{array}{c}\text { Bobot } \\
\text { Penilaian }\end{array}$ & $\begin{array}{c}\text { Nilai Bobot } \\
\text { Tertimbang } \\
\text { Kerawanan } \\
\text { Longsr }\end{array}$ \\
\hline (1) & (2) & (3) & (4) & (5) & (6) & (7) \\
\hline 1 & $\begin{array}{l}\text { Kemiringan } \\
\text { Lereng }\end{array}$ & $30 \%$ & Tinggi & $\begin{array}{l}\text { Lereng relatif cmebung degan Kemiringan } \\
\text { lereng }>40 \% \text {. } \\
\text { Lereng tersusun oleh batuan dan tanah jenis }\end{array}$ & 3 & 0,90 \\
\hline 2 & Kondisi Tanah & $15 \%$ & Tinggi & $\begin{array}{l}\text { latosol namun tidak ada struktur } \\
\text { retakan/kekar pada batuan. }\end{array}$ & 3 & 0,45 \\
\hline 3 & $\begin{array}{l}\text { Batuan Penyusun } \\
\text { Lereng }\end{array}$ & $20 \%$ & Tinggi & $\begin{array}{l}\text { Lereng tersusun oleh batuan batu formasi } \\
\text { halang yaitu perselingan batupasir,batu } \\
\text { lempung,napal dan tufa dengan sisipan breksi } \\
\text { dipengaruhi oleh turbid fan pelengseran } \\
\text { bawah laut. }\end{array}$ & 3 & 0,60 \\
\hline 4 & Curah Hujan & $15 \%$ & Tinggi & $\begin{array}{l}\text { Curah hujan mencapai } 70 \mathrm{~mm} / \mathrm{jam} \text { atau } 100 \\
\mathrm{~mm} / \text { hari curah hujan tahunan mencapai lebih } \\
\text { dari } 2500 \mathrm{~mm} / \mathrm{th} \text { yaitu } 3815 \mathrm{~mm} / \text { tahun } \\
\text { dilihat dari data rata rata curah hujan tahunan }\end{array}$ & 3 & 0,60 \\
\hline 5 & Tata Air Lereng & $7 \%$ & Sedang & $\begin{array}{l}\text { Jarang muncul rembesan- rembesan air atau } \\
\text { mata air pada lereng atau bidang kontak } \\
\text { antara }\end{array}$ & 2 & 0,14 \\
\hline & & & & $\begin{array}{l}\text { batuan kedap dengan lapisan tanah yang } \\
\text { permeable. }\end{array}$ & & \\
\hline 6 & Kegempaan & $3 \%$ & Rendah & $\begin{array}{l}\text { Lereng tidak termasuk daerah } \\
\text { rawan gempa. }\end{array}$ & 1 & 0,03 \\
\hline 7 & Vegetasi & $10 \%$ & Tinggi & Pohon Jati, Tanaman Kopi & 3 & 0,03 \\
\hline & Jumlah Bobot & $100 \%$ & & & & 2,75 \\
\hline
\end{tabular}

Sumber: Analisis 2020 
Tabel 4. Kriteria dan indikator tingkat kerawanan aspek aktivitas manusia zona berpotensi longsor Tipe C Desa Samudera Kulon (Titik 2)

\begin{tabular}{|c|c|c|c|c|c|c|}
\hline \multicolumn{7}{|c|}{ C2 Kriteria Aspek Aktivitas Manusia } \\
\hline No & Indikator & $\begin{array}{c}\text { Bobot } \\
\text { Indikator }(\%)\end{array}$ & $\begin{array}{l}\text { Sensitivitas } \\
\text { Tingkat } \\
\text { Kerawanan }\end{array}$ & Veriver & $\begin{array}{c}\text { Bobot } \\
\text { Penilaian }\end{array}$ & $\begin{array}{c}\text { Nilai Bobot } \\
\text { Tertimbang } \\
\text { Kerawanan } \\
\text { Longsr } \\
\end{array}$ \\
\hline (1) & (2) & (3) & (4) & (5) & (6) & (7) \\
\hline 1 & Pola Tanam & $10 \%$ & Rendah & $\begin{array}{l}\text { Lereng ditanami dengan pola tanam yang } \\
\text { cukup tepat, seperti pohon jati, pohon kopi } \\
\text { dimana akar tumbuhan tersebut merupakan } \\
\text { tanaman dengan jenis akar tunjan }\end{array}$ & 1 & 0,10 \\
\hline 2 & $\begin{array}{l}\text { Penggalian dan } \\
\text { Pemotongan } \\
\text { Lereng }\end{array}$ & $20 \%$ & Tinggi & $\begin{array}{l}\text { Adanya pemotongan lereng untuk perbaikan } \\
\text { drainase dan jalan }\end{array}$ & 3 & 0,60 \\
\hline 3 & $\begin{array}{l}\text { Pencetakan } \\
\text { Kolam }\end{array}$ & $10 \%$ & Rendah & Tidak melakukan pencetakan kolam. & 1 & 0,10 \\
\hline 4 & Drainase & $10 \%$ & Sedang & $\begin{array}{l}\text { Sistem drainase yang memadai dan adanya } \\
\text { usaha untuk memperbaiki drainase }\end{array}$ & 2 & 0,20 \\
\hline 5 & $\begin{array}{l}\text { Pembangunan } \\
\text { Konstruksi }\end{array}$ & $20 \%$ & Rendah & Tidak ada pembangunan Konstruksi & 1 & 0,20 \\
\hline 6 & $\begin{array}{l}\text { Kepadatan } \\
\text { Penduduk }\end{array}$ & $20 \%$ & Rendah & $\begin{array}{l}\text { Kepadatan penduduk rendah } \\
(<20 \mathrm{jiwa} / \mathrm{ha}) \text {. Yaitu } 3.130 \mathrm{jiwa} / \mathrm{ha}\end{array}$ & 1 & 0,30 \\
\hline 7 & Usaha Mitigasi & $10 \%$ & Sedang & $\begin{array}{l}\text { Terdapat usaha mitigasi bencana tapi belum } \\
\text { terkoordinasi dan } \\
\text { melembaga. }\end{array}$ & 2 & 0,20 \\
\hline & Jumlah Bobot & $100 \%$ & & & & 1.7 \\
\hline
\end{tabular}

Sumber : Analisis 2020

Tabel 5. Kriteria dan indikator tingkat kerawanan aspek fisik alami zona berpotensi longsor Tipe A Desa Samudera Kulon (Titik 3)

\begin{tabular}{|c|c|c|c|c|c|c|}
\hline \multicolumn{7}{|c|}{ C1 Kriteria Aspek Fisik Alami } \\
\hline No & Indikator & $\begin{array}{c}\text { Bobot } \\
\text { Indikator }(\%)\end{array}$ & $\begin{array}{l}\text { Sensitivitas } \\
\text { Tingkat } \\
\text { Kerawanan }\end{array}$ & Veriver & $\begin{array}{c}\text { Bobot } \\
\text { Penilaian }\end{array}$ & $\begin{array}{l}\text { Nilai Bobot } \\
\text { Tertimbang } \\
\text { Kerawanan } \\
\text { Longsr }\end{array}$ \\
\hline (1) & $(2)$ & (3) & (4) & (5) & (6) & (7) \\
\hline 1 & $\begin{array}{l}\text { Kemiringan } \\
\text { Lereng }\end{array}$ & $30 \%$ & Tinggi & $\begin{array}{l}\text { Lereng relatif cembung dengan Kemiringan } \\
\text { lereng }>40 \% \text {. }\end{array}$ & 3 & 0,90 \\
\hline 2 & Kondisi Tanah & $15 \%$ & Tinggi & $\begin{array}{l}\text { Lereng tersusun oleh batuan dan tanah jenis } \\
\text { podsolik yang namun tidak ada struktur } \\
\text { retakan/kekar pada batuan. }\end{array}$ & 3 & 0,45 \\
\hline 3 & $\begin{array}{l}\text { Batuan Penyusun } \\
\text { Lereng }\end{array}$ & $20 \%$ & Sedang & $\begin{array}{l}\text { Lereng tersusun dari batuan formasi halang } \\
\text {,adanya struktur retakan tetapi tidak miring } \\
\text { kearah lereng }\end{array}$ & 2 & 0,40 \\
\hline 4 & Curah Hujan & $15 \%$ & Tinggi & $\begin{array}{l}\text { Curah hujan mencapai } 70 \mathrm{~mm} / \mathrm{jam} \text { atau } 100 \\
\mathrm{~mm} / \text { hari curah hujan tahunan mencapai lebih } \\
\text { dari } 2500 \mathrm{~mm} / \mathrm{th} \text { yaitu } 3815 \mathrm{~mm} / \text { tahun } \\
\text { dilihat dari data rata rata curah hujan tahunan }\end{array}$ & 3 & 0,60 \\
\hline 5 & Tata Air Lereng & $7 \%$ & Sedang & $\begin{array}{l}\text { Jarang muncul rembesan- rembesan air atau } \\
\text { mata air pada lereng atau bidang kontak } \\
\text { antara } \\
\text { batuan kedap dengan lapisan tanah yang } \\
\text { permeable. }\end{array}$ & 2 & 0,14 \\
\hline 6 & Kegempaan & $3 \%$ & Rendah & $\begin{array}{l}\text { Lereng tidak termasuk daerah } \\
\text { rawan gempa. }\end{array}$ & 1 & 0,03 \\
\hline 7 & Vegetasi & $10 \%$ & Tinggi & Pohon Q-tela,Pohon Albasiar,Pohon Pisang & 3 & 0,03 \\
\hline & Jumlah Bobot & $100 \%$ & & & & 2,55 \\
\hline
\end{tabular}

Sumber :Analisis 2020 
Tabel 6. Kriteria dan indikator tingkat kerawanan aspek aktivitas manusia zona berpotensi longsor Tipe A Desa Samudera Kulon (Titik 3)

\begin{tabular}{|c|c|c|c|c|c|c|}
\hline \multicolumn{7}{|c|}{ C2 Kriteria Aspek Aktivitas Manusia } \\
\hline No & Indikator & $\begin{array}{c}\text { Bobot } \\
\text { Indikator }(\%)\end{array}$ & $\begin{array}{l}\text { Sensitivitas } \\
\text { Tingkat } \\
\text { Kerawanan }\end{array}$ & Veriver & $\begin{array}{c}\text { Bobot } \\
\text { Penilaian }\end{array}$ & $\begin{array}{c}\text { Nilai Bobot } \\
\text { Tertimbang } \\
\text { Kerawanan } \\
\text { Longsr } \\
\end{array}$ \\
\hline (1) & (2) & (3) & (4) & (5) & (6) & (7) \\
\hline 1 & Pola Tanam & $10 \%$ & Tinggi & $\begin{array}{l}\text { Lereng ditanami dengan pola tanaman yang } \\
\text { tidak tepat dan sangat sensitif, berupa } \\
\text { tanaman musiman perkebunan dengan jenis } \\
\text { tanaman ubi kayu seperti pohon Qt-tela,pohon } \\
\text { pisang,pohon albasiar. Jenis pohon tersebut } \\
\text { memiliki akar yang tidak cukup kokoh } \\
\text { menjaga struktur tanah tetap kuat.. }\end{array}$ & 3 & 0,30 \\
\hline 2 & $\begin{array}{l}\text { Penggalian dan } \\
\text { Pemotongan } \\
\text { Lereng }\end{array}$ & $20 \%$ & Rendah & $\begin{array}{l}\text { Tidak melakukan penggalian/ pemotongan } \\
\text { lereng }\end{array}$ & 1 & 0,20 \\
\hline 3 & $\begin{array}{l}\text { Pencetakan } \\
\text { Kolam }\end{array}$ & $10 \%$ & Rendah & Tidak melakukan pencetakan kolam. & 1 & 0,10 \\
\hline 4 & Drainase & $10 \%$ & Tinggi & $\begin{array}{l}\text { Sistem drainase yang tidak memadai dan } \\
\text { tidak adanya usaha untuk memperbaiki } \\
\text { drainase }\end{array}$ & 3 & 0,30 \\
\hline 5 & $\begin{array}{l}\text { Pembangunan } \\
\text { Konstruksi }\end{array}$ & $20 \%$ & Rendah & Tidak ada pembangunan Konstruksi & 1 & 0,20 \\
\hline 6 & $\begin{array}{l}\text { Kepadatan } \\
\text { Penduduk }\end{array}$ & $20 \%$ & Rendah & $\begin{array}{l}\text { Kepadatan penduduk rendah } \\
(<20 \mathrm{jiwa} / \mathrm{ha}) \text {. Yaitu } 3.130 \mathrm{jiwa} / \mathrm{ha}\end{array}$ & 1 & 0,30 \\
\hline 7 & Usaha Mitigasi & $10 \%$ & Sedang & $\begin{array}{l}\text { Terdapat usaha mitigasi bencana tapi belum } \\
\text { terkoordinasi dan } \\
\text { melembaga. }\end{array}$ & 2 & 0,20 \\
\hline & Jumlah Bobot & $100 \%$ & & & & 1.6 \\
\hline
\end{tabular}

Sumber: Analisis 2020

\subsection{Hasil Analisis Perhitungan}

Hasil analisis titik 1 zona berpotensi longsor tipe $\mathbf{C}$ :

a. Aspek fisik alami total nilai bobot tertimbang (a) $=1,58$

b. Aspek aktifitas manusia total nilai bobot tertimbang $(b)=1,9$

c. Tingkat kerawanan zona berpotensi longsor $\left(\frac{a+b}{2}\right)=\frac{1,58+1,9}{2}=1,74$ Sedang

Dengan demikian tingkat kerawanan zona berpotensi longsor di titik 1 Desa Samudera Kulon adalah

\section{Hasil analisis titik 2 zona berpotensi longsor tipe A :}

a. Aspek fisik alami total nilai bobot tertimbang (a) $=2,75$

b. Aspek aktifitas manusia total nilai bobot tertimbang $(\mathrm{b})=1,7$

c. Tingkat kerawanan zona berpotensi longsor $\left(\frac{a+b}{2}\right)=\frac{2,75+1,7}{2}=2,225$ Sedang

Dengan demikian tingkat kerawanan zona berpotensi longsor di titik 2 Desa Samudera Kulon adalah

\section{Hasil analisis titik 3 zona berpotensi longsor tipe A :}

a. Aspek fisik alami total nilai bobot tertimbang (a) $=2,55$

b. Aspek aktifitas manusia total nilai bobot tertimbang $(\mathrm{b})=1,6$

c. Tingkat kerawanan zona berpotensi longsor $\left(\frac{a+b}{2}\right)=\frac{2,55+1,6}{2}=2,075$

Dengan demikian tingkat kerawanan zona berpotensi longsor di titik 3 Desa Samudera Kulon adalah Sedang.

\section{KESIMPULAN}

Hasil analisis dari ke-tiga titik pengamatan total nilai bobot tertimbang berdasarkan aspek fisik alami dan aspek aktivitas manusia diperoleh nilai ; Pada Lokasi titik 1 dengan Type Zona C dan Lokasi titik 2 dan 3 dengan Type Zona A, diperoleh total nilai bobot tertimbang kedua aspek adalah 1,74 (sedang), titik $2=2,175$ (sedang), dan titik $3=2,24$ (sedang). 
Dengan demikian tingkat kerawanan longsor lereng zona di Desa Samudera Kulon Kecamatan Gumelar dapat diambil kesimpulan tergolong sedang.

\section{DAFTAR PUSTAKA}

[1] BBSDLP] Balai Besar Litbang Sumberdaya Lahan Pertanian. (2009). Identifikasi dan Karakterisasi Lahan Rawan Longsor dan Rawan Erosi di Dataran Tinngi Untuk Mendukung Keberlanjutan Pengelolaan Sumberdaya Lahan Pertanian. Bogor: Balai Besar Litbang Sumberdaya Lahan Pertanian.

[2] Badan Penanggulangan Bencana Daerah. (2012). Tata Ruang dan Pelaksanaan Teknis Kabupaten Banyumas. Banyumas.

[3] BAPEDA. (2012). Peta Administrasi Kabupaten Banyumas . Banyumas.

[4] Direktorat Jenderal Penataan Ruang. (2007). Pedoman,Penataan Ruang Kawasan Rawan Bencana Longsor. Jakarta: Departemen Pekerja Umum.

[5] Direktorat Jenderal Penataan Ruang. (2008). Modul Terapan Pedoman Penataan Ruang Kawasan Rawan Bencana Longsor. Jakarta: Departemen Pekerjaan Umum

[6] Ilyas, T. (2011). Tanah Longsor (Landslide. Bahan Ajar MPKT-B.

[7] Pemerintah Desa Samudera Kulon. (2018). Data Bencana Desa Samudera Kulon.

[8] Pemerintah Desa Samudera Kulon. (2020). Data Administrasi Desa Samudera Kulon Kecamatan Gumelar. Samudera Kulon. 
